\title{
Skeletal System Part
}

National Cancer Institute

\section{Source}

National Cancer Institute. Skeletal System Part. NCI Thesaurus. Code C34076.

Any component of the framework, including bone and cartilage, that supports and/or protects the soft tissues of vertebrate animals. 